\title{
EFFECT OF PLANTING ARRANGEMENTS ON PRODUCTIVITY OF COTTON + MUNGBEAN INTERCROPPING SYSTEMS
}

\author{
M. F. A. I. Tabib ${ }^{1}$, M. A. Karim², M. M. Haque², Q. A. Khaliq ${ }^{2}$ and A. R. M. Solaiman² \\ ${ }^{1}$ Deputy Director, Cotton Development Board, Dhaka Region, Dhaka. \\ ${ }^{2}$ Professor, Bangabandhu Sheikh Mujibur Rahman Agricultural University, Salna, Gazipur. \\ Corresponding author: tabibfai@gmail.com
}

Key words: Spatial arrangement, cotton, mungbean, intercropping

\begin{abstract}
An experiment was conducted at the Cotton Research Farm, Sreepur, Gazipur during 2009-10 growing season to maximize the benefit of cotton + mungbean intercropping system through appropriate planting arrangement of component crops in the system. Performance of eight different planting arrangements, such as 1, 2, 3 and 4 rows of mungbean in between single row of cotton and 4, 5, 6 and 7 rows of mungbean in between paired row cotton ware compared against their sole cropping. Intercropping and mungbean density reduced individual yield of cotton and mungbean compared to their sole cropping but increased equivalent yield of both cotton and mungbean. The highest seed cotton (2951 kg ha $\left.{ }^{-1}\right)$ and mungbean $\left(3373 \mathrm{~kg} \mathrm{ha}^{-1}\right)$ equivalent yield was recorded from the paired row cotton +4-row mungbean. The land equivalent ratio of the same combination indicated $31 \%$ yield advantage over sole cropping. The same plating arrangement also recorded the highest gross return (Tk. $118039 \mathrm{ha}^{-1}$ ), gross margin (Tk. 60220 $\mathrm{ha}^{-1}$ ) and BCR (2.04). Thus, the panting arrangement of paired row cotton and 4 rows of mungbean could be grown for higher productivity and economic return in the system.
\end{abstract}

\section{Introduction}

Cotton is an industrial crop as well as cash crop to the farmer's in Bangladesh. The area and production of cotton in the country are limited compared to its annual demand of 4.2 million bales in 2011 (Anon., 2011; Adams et al., 2011). To meet the demand vertical expansion is the appropriate option rather than horizontal one from the limited land resources of the country. Intercropping is the proven option of vertical expansion of cotton that can help to ensure both subsistence and disposable income to the farmers (Singh and Jodha, 1990). Long duration with initially slow growing cotton and short duration fast maturing mungbean appeared to be the most compatible companion crops in the intercropping system (Rao, 1991) and also been proved to be productive and economic in the tropical countries (Sayampol and Changsalak, 1997). The overall productivity in terms of cotton equivalent yield was generally higher in intercropping system than that in sole stand (Maitra et al., 2000).The productivity and efficiency of intercropping system depends, to a large extent, on the nature and extent of plant competition (Harper, 1977) and the spatial arrangement and densities of the component crops (Nataranjan, 1990). Aasim et al. (2008) revealed that paired row cotton seemed well compared to single row cultivation for easy harvesting and handling of intercrop without any damage to the base crop cotton.

Mungbean (Vigna radiata) is a short duration crop that matures at around 60-70 days, which could be fitted well in cotton + mungbean intercropping system. However, it is necessary to determine the optimum population of mungbean as a companion crop to minimize competition with the main cotton crop. This experiment was therefore, undertaken to determine the appropriate planting arrangement of both cotton and mungbean in order to achieve maximum productivity and economic return from cotton + mungbean intercropping system. 
Tabib et al.

The experiment was conducted at the Cotton Research Farm, Sreepur, Gazipur during 2009-10 growing season. The site was high land and located in the centre of Madhupur Tract of agro-ecological zone (AEZ)-28. The soil of the experimental site belongs to the Salna series and is classified as Shallow RedBrown Terrace type which falls under the order Inceptisols of soil taxonomy (Anon., 1988; Brammer, 1996). Experiment was laid out in randomized complete block design (RCBD) with three replications. The unit plot size was $5.4 \mathrm{~m}$ x $4.5 \mathrm{~m}$. Eight different plating arrangements of cotton and mungbean were compared with paired row and single row sole cotton and sole mungbean. Cotton population was $100 \%$ of sole cropping in all arrangements but mungbean population was $28,44,56,67,78,83$ and $111 \%$ of sole mungbean. Cotton var. CB-10 and mungbean var. BUmung-4 were used for the experiment. Single row cotton +1 -row
mungbean

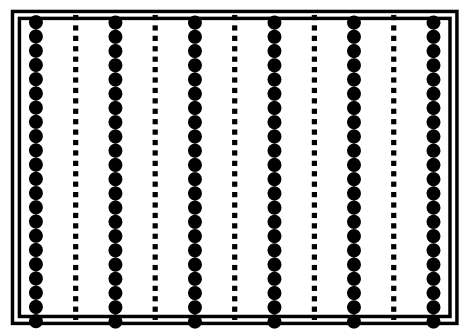

Single row cotton +4 -row mungbean

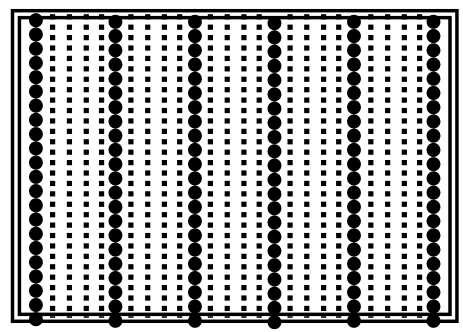

Paired row cotton +6 -row mungbean

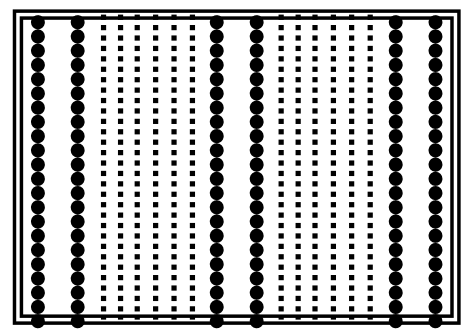

Single row cotton + 2-row mungbean

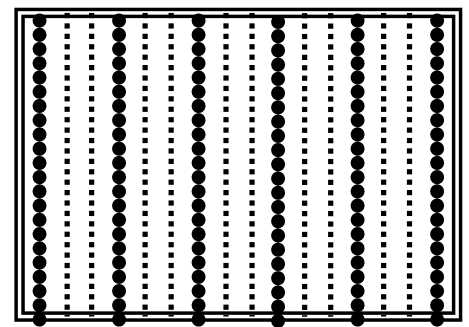

Paired row cotton +4 -row mungbean

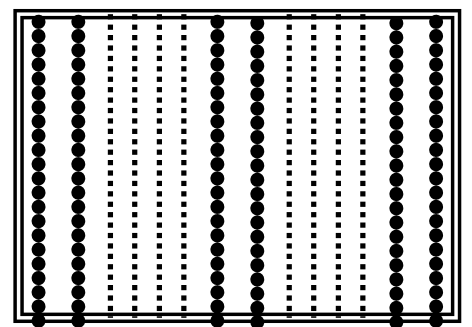

Paired row cotton + 7-row mungbean

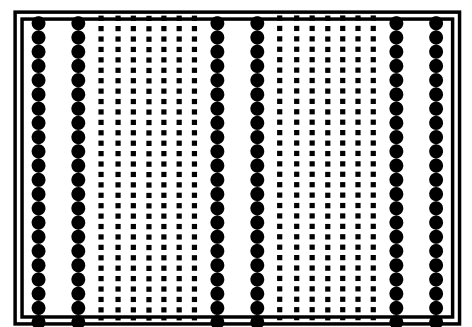

Single row cotton + 3-row mungbean

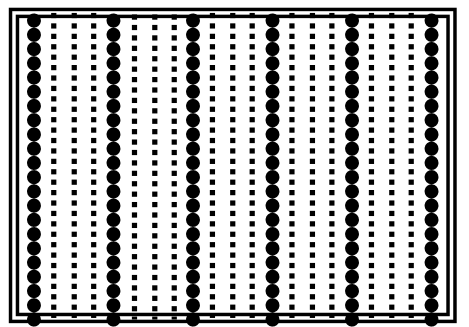

Paired row cotton +5 -row mungbean

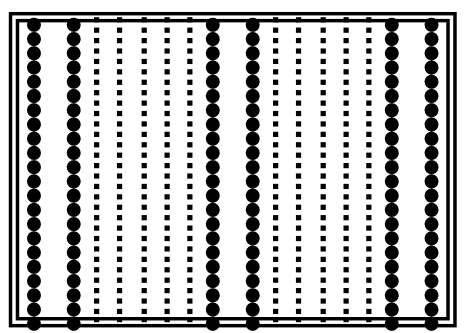

Legend:

œececeobitton

Mungbean

Fig. 1. Sketch of the different spatial arrangements of cotton and mungbean

All the treatments except sole mungbean was fertilized with 23-34-17.5-18-4.60-2.2-1.90 kg of N P K S $\mathrm{Zn} \mathrm{B}$ and $\mathrm{Mg} \mathrm{ha}^{-1}$, respectively as urea, triple super phosphate, muriate of potash, gypsum, zinc sulphate, borax and magnesium sulphate. Additional three top dressing of $23 \mathrm{~kg} \mathrm{~N}$ each and 22.5-30-17.5 kg K were applied at 20, 40 and 60 days after sowing (Anon., 2009). Sole mungbean was fertilized at the rate of 23-17-18 kg of N P K ha ${ }^{-1}$, respectively. Liming was done 25 days before sowing by using dolochun $\mathrm{CaMg}\left(\mathrm{CO}_{3}\right)_{2}$ at the rate of 2 tons ha ${ }^{-1}$ while 5 tons of cowdung ha ${ }^{-1}$ was incorporated with the soil at the time of final land preparation. Both cotton and mungbean were sown on 21 July 2009. Cotton and 
Productivity of Cotton+Mungbean Intercropping Systems

mungbean seeds were soaked into water for 3 hours just before sowing. The mungbean seeds were treated with Vitavex-200 at the rate of $3 \mathrm{~g} \mathrm{~kg}^{-1}$ and cotton seed with gaucho at the rate of $5 \mathrm{~g} \mathrm{~kg}^{-1}$. Three seeds of cotton and 3-4 seeds of mungbean per hill were hand planted in dibbling method. Cotton took 5-7 days and mungbean took 3-5 days to emergence. Immediately after sowing light irrigation was given to ensure uniform crop emergence. Subsequent irrigation was also provided to avoid any moisture stress. Two times weeding, eight times insecticide spraying, two times hand picking of bollworm larvae were performed to keep the field free from pest. Mature mungbean pods were harvested at 55 and 65 DAS and mature seed cotton in three installments at 150, 165 and 180 DAS.

Data on agronomic traits of cotton and qualitative characters of cotton including fibre length, fibre strength, micronaire and ginning out turn was also recorded. Lint and seed yield was recorded after separation of seed and lint from seed cotton by using 'Lummus 20- saw' ginning machine. Fibre length, fibre strength and micronaire were measured by using Fibrograph instrument, Pressly meter and micronaire testing instruments, respectively. Data on yield and yield components of mungbean was measured at harvest from randomly selected plants. The productivity of cotton + mungbean intercropping system was assessed by land equivalent ratio (LER), monetary advantage index (MAI) and equivalent yield of cotton and mungbean by using the standard formula as well as cost and benefit analysis was also calculated. The data were analyzed statistically and means were separated by Least Significance Difference (LSD) test at 5\% level of significance (Gomez and Gamez, 1984).

The formula used for different parameters are given below.

Ginning outturn (\%) $\quad=\frac{\text { Weight of lint }}{\text { Weight of seed cotton }} \times 100$

Seed index $=$ Weight of 100-seed

Lint Index $\quad=\frac{\text { Weight of lint }}{\text { Weight of seed }} \times \quad$ Seed index

Harvest index (HI\%) $\quad=\frac{\text { Grain yield }}{\text { Total biological yield }} \times 100$

Land equivalent ratio (LER) $=\frac{\text { Intercrop yield of cotton }}{\text { Sole crop yield of cotton }}+\frac{\text { Intercrop yield of mungbean }}{\text { Sole crop yield of mungbean }}$

Monetary advantage index (MAI) $\quad=\quad$ Value of combined intercrop $\quad x \quad \frac{\text { (LER-1) }}{\text { LER }}$

Seed cotton equivalent yield $=\begin{gathered}\text { Intercrop yield of } \\ \text { seed cotton }\left(\mathrm{kg} \mathrm{ha}^{-1}\right)\end{gathered}+\frac{\begin{array}{c}\text { Intercrop yield of mungbean }\left(\mathrm{kg} \mathrm{ha}^{-1}\right) \times \\ \text { Selling price of mungbean }\end{array}}{\text { Selling price of seed cotton }(\mathrm{Tk})}$

Mungbean equivalent yield $=\underset{\begin{array}{c}\text { Intercrop yield of } \\ \text { mungbean }\left(\mathrm{kg} \mathrm{ha}^{-1}\right)\end{array}}{\frac{\text { Intercrop yield of seed cotton }\left(\mathrm{kg} \mathrm{ha}^{-1}\right) \times}{\text { Selling price of seed cotton }}}$

Gross return $\left(\mathrm{Tk} . \mathrm{ha}^{-1}\right)=$ Total yield $\left(\mathrm{kg} \mathrm{ha}^{-1}\right) \times$ Unit market price $\left(\mathrm{Tk} . \mathrm{kg}^{-1}\right)$

Gross margin $\left(\right.$ Tk. ha $\left.{ }^{-1}\right)=$ Gross return- Total variable cost 
Tabib et al.

Benefit cost ratio $(\mathrm{BCR})=$ Gross return $/$ Total variable cost

\section{Results and Discussion}

\section{Yield components and seed cotton yield}

\section{Number of sympods and monopods plant ${ }^{-1}$ in cotton}

Number of sympods and monopods plant ${ }^{-1}$ varied with the variation in spatial arrangement of cotton and mungbean in intercropping systems (Table 1). Cotton under single row sole cropping produced the highest number of sympods plant ${ }^{-1}$ (17.97) but lowest number of monopods plant ${ }^{-1}(0.73)$, which was significantly different from intercropping treatments. Sympods plant ${ }^{-1}$ was decreased with increased in mungbean row number in between cotton rows and the lowest number of sympods plant ${ }^{-1}$ (8.67) was in single row cotton+4-row mungbean arrangement $\left(T_{7}\right)$. But monopods plant ${ }^{-1}$ was increased with the increasing competition between component crops under intercropping systems and the highest was observed in single row cotton +4 -row mungbean arrangement $\left(\mathrm{T}_{7}\right)$. Higher number of branches plant ${ }^{-1}$ in sole cotton was also reported by Oad et al. (2007) under cotton + pigeaon pea intercropping system and Mahatale et al. (2008) in cotton based intercropping system.

\section{Number of bolls plant ${ }^{-1}$ and single boll weight in cotton}

Cotton yield was determined by the number of bolls plant ${ }^{-1}$ and single boll weight, which was significantly differed by the spatial arrangements of cotton and mungbean under cotton + mungbean intercropping systems (Table 1). Cotton under single row sole cropping produced the highest number of bolls plant ${ }^{-1}$ (28.73) and single boll weight (6.24 g) compared to other intercropping treatments. The spatial arrangement of densely populated and closer spacing produced lower number of bolls plant ${ }^{-1}$ and single boll weight. The lowest number of bolls plant ${ }^{-1}(14.60)$ and single boll weight $(5.00 \mathrm{~g})$ was recorded from single row cotton +4 -row mungbean $\left(T_{7}\right)$. Higher number of bolls plant ${ }^{-1}$ under sole cropping was also reported by Oad et al. (2007) and reduced bolls weight from densely populated cotton was reported by Junior et al. (2003).

\section{Seed cotton yield}

Seed cotton yield is considered as economic yield, which is the function of number of bolls palnt ${ }^{-1}$ and single boll weight although it was considerably influenced by the variations in spatial arrangements of cotton and mungbean under cotton + mungbean intercropping systems (Table 1). The maximum seed cotton yield (2885 kg ha $\left.{ }^{-1}\right)$ was recorded in single row sole cotton $\left(\mathrm{T}_{1}\right)$ followed by paired row sole cotton $\left(\mathrm{T}_{2}\right)$. Intercropping reduced the seed cotton yield by 2.43 to $30.16 \%$. This yield reduction was occurred due to the competition for growth resources between component crops under intercropping systems. Under intercropping conditions, the highest seed cotton yield was recorded from the treatment of paired row cotton +4 -row mungbean $\left(\mathrm{T}_{8}\right)$ and the lowest $\left(2015 \mathrm{~kg} \mathrm{ha}^{-1}\right)$ single row cotton +4 -row mungbean arrangement $\left(\mathrm{T}_{7}\right)$. The reduction in seed cotton yield due to growing intercrops in association with cotton was also reported by Sanjay et al. (2003), Basavarajappa et al. (2003) and Khan et al. (2001).

Table 1. Seed yield and yield components of cotton as influenced by different planting arrangements of cotton and mungbean in intercropping systems

\begin{tabular}{c|c|c|c|c|c}
\hline Treatments & $\begin{array}{c}\text { No. of } \\
\text { sympods } \\
\text { plant }^{-1}\end{array}$ & $\begin{array}{c}\text { No. of } \\
\text { monopods } \\
\text { plant }^{-1}\end{array}$ & $\begin{array}{c}\text { No. of bolls } \\
\text { plant }^{-1}\end{array}$ & $\begin{array}{c}\text { Single boll } \\
\text { weight (g) }\end{array}$ & $\begin{array}{c}\text { Seed cotton } \\
\text { yield } \\
\text { (kg ha }^{-1)}\end{array}$ \\
\hline $\mathrm{T}_{1}$ & 17.97 & 0.733 & 28.73 & 6.237 & 2885 \\
$\mathrm{~T}_{2}$ & 16.87 & 0.900 & 25.27 & 6.187 & 2639 \\
$\mathrm{~T}_{4}$ & 16.33 & 1.267 & 23.50 & 5.940 & 2543
\end{tabular}


Productivity of Cotton+Mungbean Intercropping Systems

\begin{tabular}{cccccc}
$\mathrm{T}_{5}$ & 15.43 & 1.533 & 20.70 & 5.800 & 2520 \\
$\mathrm{~T}_{6}$ & 10.07 & 2.133 & 18.33 & 5.163 & 2280 \\
$\mathrm{~T}_{7}$ & 8.667 & 2.500 & 14.60 & 5.000 & 2015 \\
$\mathrm{~T}_{8}$ & 16.43 & 1.267 & 23.83 & 6.047 & 2575 \\
$\mathrm{~T}_{9}$ & 15.50 & 1.433 & 23.07 & 5.917 & 2460 \\
$\mathrm{~T}_{10}$ & 12.97 & 1.667 & 20.65 & 5.560 & 2343 \\
$\mathrm{~T}_{11}$ & 11.20 & 1.967 & 19.20 & 5.467 & 2292 \\
\hline $\operatorname{LSD}(0.05)$ & 1.07 & 0.23 & 1.77 & 0.196 & 132.80 \\
\hline $\mathrm{CV}(\%)$ & 4.40 & 8.59 & 4.73 & 2.01 & 3.16 \\
\hline
\end{tabular}

$\mathrm{T}_{1}=$ Sole single row cotton, $\mathrm{T}_{2}=$ Sole paired row cotton, $\mathrm{T}_{4}=$ Single row cotton+1-row mungbean, $\quad \mathrm{T}_{5}=$ Single row cotton+2-row mungbean, $\mathrm{T}_{6}=$ Single row cotton +3 -row mungbean, $\mathrm{T}_{7}=$ Single row cotton +4 -row mungbean, $\mathrm{T}_{8}=$ Paired row cotton +4 -row mungbean, $\mathrm{T}_{9}=$ Paired row cotton+5-row mungbean, $\mathrm{T}_{10}=$ Paired row cotton+6-row mungbean, $\mathrm{T}_{11}=$ Paired row cotton +7 -row mungbean.

\section{Yield and yield components of mungbean}

Number of pods plant ${ }^{-1}$, single pod weight, number of seeds pod ${ }^{-1}$ and 1000 -seed weight is an important attribute of yield in grain legumes. These attributes are varied significantly with the variations in spatial arrangements of cotton and mungbean (Table 2). Mungbean under sole cropping $\left(\mathrm{T}_{3}\right)$ recorded the highest number of pods plant ${ }^{-1}$ (26.27), single pod weight $(0.70 \mathrm{~g})$, number of seeds pod $^{-1}(12.93)$ and 1000 -seed weight (43.70 g). All the yield components were reduced with increasing mungbean density in closer spatial arrangements under intercropping systems. The lowest number of pods plant ${ }^{-1}$ (15.40), single pod weight $(0.48 \mathrm{~g})$, number of seeds $\operatorname{pod}^{-1}(10.43)$ and 1000 -seed weight (34.88 g) was recorded from the treatment of single row cotton+4-row mungbean $\left(\mathrm{T}_{7}\right)$. Similar result of the highest number of pods plant ${ }^{-1}$, seeds pod $^{-1}$ and 1000 -seed weight from sole cropping compared to intercropped mungbean was reported by Khan et al. (2012).

\section{Harvest index in mungbean}

Variations in spatial arrangements of cotton and mungbean in intercropping systems significantly affected the harvest index of mungbean (Table 2). The highest harvest index (33.64\%) was found in sole cropping while lowest harvest index (16.72\%) was recorded from the single row cotton + 4-row mungbean $\left(\mathrm{T}_{7}\right)$. Bhatti et al. (2008) reported a higher harvest index in sole mungbean than the intercropped mungbean.

\section{Seed yield}

Seed yield in mungbean was found to be varied with the variations in spatial arrangements of cotton and mungbean in intercropping systems (Table 2). Sole cropping of mungbean showed superiority in seed yield (1322 kg ha ${ }^{-1}$ ), which was significantly different from other treatments due to the highest number of pods plant ${ }^{-1}$, single pod weight, seed pod $^{-1}$, 1000-seed weight and plant population. Under intercropping condition the highest seed yield was found in paired row cotton +7 -row mungbean $\left(\mathrm{T}_{11}\right)$. Crop competition in densely populated spatial arrangement reduces seed yield in mungbean and the lowest seed yield (301.7 $\mathrm{kg} \mathrm{ha}^{-1}$ ) was recorded from the treatment of single row cotton + 1-row mungbean $\left(\mathrm{T}_{4}\right)$. Onuh et al. (2011) recorded the highest seed yield from the sole mungbean compared to the intercrop mungbean.

Table 2. Seed yield and yield components of mungbean as influenced by different spatial planting arrangements of cotton and mungbean intercropping systems

\begin{tabular}{c|c|c|c|c|c|c}
\hline Treatments & $\begin{array}{c}\text { No. of } \\
\text { pods plant } \\
1\end{array}$ & $\begin{array}{c}\text { Single pod } \\
\text { weight (g) }\end{array}$ & $\begin{array}{c}\text { No. of seeds } \\
\text { pod }^{-1}\end{array}$ & $\begin{array}{c}\text { 1000-seed } \\
\text { weight } \\
(\mathrm{g})\end{array}$ & $\begin{array}{c}\text { Harvest } \\
\text { index } \\
(\%)\end{array}$ & $\begin{array}{c}\text { Seed yield } \\
\left(\mathrm{kg} \mathrm{ha}^{-1}\right)\end{array}$ \\
\hline $\mathrm{T}_{3}$ & 26.27 & 0.700 & 12.93 & 43.70 & 33.64 & 1322.0
\end{tabular}


Tabib et al.

\begin{tabular}{ccccccc}
$\mathrm{T}_{4}$ & 23.60 & 0.583 & 12.37 & 41.28 & 21.87 & 301.7 \\
$\mathrm{~T}_{5}$ & 19.87 & 0.576 & 11.47 & 38.70 & 23.05 & 453.0 \\
$\mathrm{~T}_{6}$ & 16.80 & 0.503 & 11.23 & 35.85 & 20.13 & 566.0 \\
$\mathrm{~T}_{7}$ & 15.40 & 0.483 & 10.43 & 34.88 & 16.72 & 526.7 \\
$\mathrm{~T}_{8}$ & 23.67 & 0.620 & 12.47 & 41.36 & 29.55 & 441.0 \\
$\mathrm{~T}_{9}$ & 21.53 & 0.580 & 11.77 & 39.73 & 21.12 & 472.0 \\
$\mathrm{~T}_{10}$ & 19.07 & 0.556 & 11.40 & 38.51 & 20.17 & 519.0 \\
$\mathrm{~T}_{11}$ & 18.40 & 0.530 & 11.27 & 37.90 & 20.80 & 571.0 \\
\hline LSD (0.05) & 2.05 & 0.017 & 0.59 & 1.92 & 3.66 & 76.21 \\
$\mathrm{CV}(\%)$ & 5.78 & 3.76 & 2.92 & 2.84 & 9.18 & 7.66 \\
\hline
\end{tabular}

$\mathrm{T}_{3}=$ Sole mungbean, $\mathrm{T}_{4}=$ Single row cotton+1-row mungbean, $\mathrm{T}_{5}=$ Single row cotton+2-row mungbean, $\mathrm{T}_{6}=$ Single row cotton $+3-$ row mungbean, $\mathrm{T}_{7}=$ Single row cotton +4 -row mungbean, $\mathrm{T}_{8}=$ Paired row cotton +4 -row mungbean, $\mathrm{T}_{9}=$ Paired row cotton +5 -row mungbean, $\mathrm{T}_{10}=$ Paired row cotton+6-row mungbean, $\mathrm{T}_{11}=$ Paired row cotton+7-row mungbean .

\section{Gin and fibre quality of cotton}

\section{Gin properties}

Gin properties of cotton was determined by GOT, seed index and lint index and these properties were significantly varied with the variations in spatial arrangements of cotton and mungbean in intercropping systems (Table 3). Cotton under sole cropping showed better performance in GOT (38.07\%), seed index $(10.67 \mathrm{~g})$ and lint index $(6.81 \mathrm{~g})$. The spatial arrangement of single row cotton + 4-row mungbean $\left(\mathrm{T}_{7}\right)$ was found lowest GOT (30.12\%), seed index (7.87g) and lint index (3.52g) of cotton. The reasons for that reduction may be due to the intercropping and spatial arrangements.

\section{Fibre quality of cotton}

Fibre length, strength and micronaire are the measure of fibre quality of cotton and which was significantly affected by the different spatial arrangements of cotton and mungbean in intercropping systems (Table 3). Cotton under sole cropping showed better in fibre length $(2.81 \mathrm{~cm})$, fibre strength (84.92) and micronaire value (4.53) compared to intercrop. The lowest fibre length $(2.60 \mathrm{~cm})$, poor strength and low micronaire were measured in cotton under single row cotton+4-row mungbean $\left(\mathrm{T}_{7}\right)$. The result indicated that the increase in plant density, decreasing the fibre length, strength and micronaire in cotton.

Table 3. Gin and fibre quality of cotton as influenced by different spatial arrangements of cotton and mungbean under intercropping systems

\begin{tabular}{c|c|c|c|c|c|c}
\hline Treatments & GOT (\%) & $\begin{array}{c}\text { Seed index } \\
(\mathrm{g})\end{array}$ & $\begin{array}{c}\text { Lint index } \\
(\mathrm{g})\end{array}$ & $\begin{array}{c}\text { Fibre length } \\
(\mathrm{cm})\end{array}$ & $\begin{array}{c}\text { Fibre } \\
\text { strength } \\
\text { (PSI) }\end{array}$ & $\begin{array}{c}\text { Micronaire } \\
\text { value }\end{array}$ \\
\hline $\mathrm{T}_{1}$ & 38.07 & 10.67 & 6.810 & 2.81 & 84.92 & 4.533 \\
$\mathrm{~T}_{2}$ & 37.76 & 10.50 & 6.580 & 2.80 & 84.60 & 4.433 \\
$\mathrm{~T}_{4}$ & 35.11 & 10.11 & 5.680 & 2.72 & 83.69 & 4.400 \\
$\mathrm{~T}_{5}$ & 33.57 & 9.757 & 5.130 & 2.66 & 83.09 & 4.400 \\
$\mathrm{~T}_{6}$ & 31.98 & 8.407 & 4.063 & 2.62 & 82.78 & 4.100 \\
$\mathrm{~T}_{7}$ & 30.41 & 7.867 & 3.523 & 2.60 & 82.73 & 4.067 \\
$\mathrm{~T}_{8}$ & 36.24 & 10.15 & 6.053 & 2.73 & 84.23 & 4.433 \\
$\mathrm{~T}_{9}$ & 34.19 & 9.817 & 5.303 & 2.70 & 83.50 & 4.400 \\
$\mathrm{~T}_{10}$ & 30.12 & 9.607 & 4.297 & 2.65 & 82.92 & 4.367 \\
\end{tabular}


Productivity of Cotton+Mungbean Intercropping Systems

\begin{tabular}{ccccccc}
$\mathrm{T}_{11}$ & 32.78 & 9.563 & 4.797 & 2.64 & 82.87 & 4.267 \\
\hline $\mathrm{LSD}_{(0.05)}$ & 2.86 & 0.597 & 0.80 & 0.15 & 1.86 & 0.31 \\
$\mathrm{CV} \%$ & 4.91 & 3.61 & 8.94 & 3.39 & 1.30 & 4.90 \\
\hline
\end{tabular}

$\mathrm{T}_{1}=$ Sole single row cotton, $\mathrm{T}_{2}=$ Sole paired row cotton, $\mathrm{T}_{4}=$ Single row cotton +1 -row mungbean, $\mathrm{T}_{5}=$ Single row cotton +2 -row mungbean, $\mathrm{T}_{6}=$ Single row cotton+3-row mungbean, $\mathrm{T}_{7}=$ Single row cotton+4-row mungbean, $\mathrm{T}_{8}=$ Paired row cotton +4 -row mungbean, $\mathrm{T}_{9}=$ Paired row cotton+5-row mungbean, $\mathrm{T}_{10}=$ Paired row cotton+6-row mungbean, $\mathrm{T}_{11}=$ Paired row cotton +7 -row mungbean

\section{Assessment of intercrop productivity}

\section{Land equivalent ratio}

The land equivalent ratio (LER) is the main index of intercropping advantage and intercrop productivity. The LER varied significantly due to the variations in spatial arrangements of cotton and mungbean in intercropping systems (Table 4). The highest LER (1.31) was recorded in paired row cotton + 4-row mungbean $\left(T_{8}\right)$ and the lowest (1.10) from single row cotton+4-row mungbean $\left(T_{7}\right)$. Yield advantages in intercropping system over sole cropping was also reported by Eskandari (2012), Das et al. (2012) and Islam et al. (2004).

\section{Equivalent yield}

Intercrop productivity was evaluated by the equivalent yield of the component crops. The highest seed cotton (2951 kg ha $\mathrm{kg}^{-1}$ and mungbean equivalent yield (3373 kg ha $\left.{ }^{-1}\right)$ was achieved from the treatment of paired row cotton +4 -row mungbean $\left(\mathrm{T}_{8}\right)$ and the lowest seed cotton $\left(2475 \mathrm{~kg} \mathrm{ha}^{-1}\right)$ and mungbean $(2829$ $\mathrm{kg} \mathrm{ha}^{-1}$ ) from single row cotton +4 -row mungbean $\left(\mathrm{T}_{7}\right)$. The result indicated a definite yield and intercropping advantage with paired row cotton+4-row mungbean in intercropping systems. Islam et al. (2004) also found the highest maize equivalent yield from maize paired row plus four rows of bushbean combination in maize + bushbean intercropping system. Higher equivalent yield under intercropping situation than that of sole crops was also reported by Patel et al. (2010), Das et al. (2012) and Ali et al. (2007).

\section{Monetary advantage index}

Another productivity indices monetary advantage index (MAI) significantly varied due to the variations in spatial arrangements of cotton and mungbean in intercropping systems (Table 4). The highest MAI (27670) was calculated from the treatment of paired row cotton +4 -row mungbean $\left(\mathrm{T}_{8}\right)$ and the lowest MAI (8931) was found in single row cotton +4 -row mungbean $\left(T_{7)}\right.$. The result indicated that paired row cotton is advantageous over single row in intercropping situation and 4-row mungbean in between paired row cotton performed the best in terms of MAI. Aasim et al. (2008) also revealed that positive monetary index obtained from intercropping cotton with cowpea and sorghum.

Table 4. Land equivalent ratio (LER), equivalent yield of cotton and mungbean and monetary advantage index (MAI) as influenced by different spatial arrangements in intercropping systems

\begin{tabular}{c|c|c|c|c}
\hline Treatments & LER & $\begin{array}{c}\text { Seed cotton equivalent } \\
\text { yield } \mathrm{kg} \mathrm{ha}^{-1}\end{array}$ & $\begin{array}{c}\text { Mungbean equivalent yield } \\
\mathrm{kg} \mathrm{ha}^{-1}\end{array}$ & MAI \\
\hline $\mathrm{T}_{1}$ & 1.00 & 2885 & 3297 & - \\
$\mathrm{T}_{2}$ & 1.00 & 2639 & 3016 & - \\
$\mathrm{T}_{3}$ & 1.00 & 1156 & 1322 & - \\
$\mathrm{T}_{4}$ & 1.11 & 2807 & 3208 & 11030 \\
$\mathrm{~T}_{5}$ & 1.22 & 2916 & 3333 & 20800 \\
$\mathrm{~T}_{6}$ & 1.22 & 2776 & 3172 & 20010 \\
$\mathrm{~T}_{7}$ & 1.10 & 2475 & 2829 & 8931
\end{tabular}


Tabib et al.

\begin{tabular}{ccccc}
$\mathrm{T}_{8}$ & 1.31 & 2951 & 3373 & 27670 \\
$\mathrm{~T}_{9}$ & 1.29 & 2857 & 3265 & 25290 \\
$\mathrm{~T}_{10}$ & 1.28 & 2797 & 3197 & 24550 \\
$\mathrm{~T}_{11}$ & 1.30 & 2791 & 3190 & 25790 \\
\hline $\mathrm{LSD}_{(0.05)}$ & 0.05 & 145.40 & 166.20 & 5825 \\
$\mathrm{CV} \%$ & 2.70 & 3.23 & 3.23 & 16.22 \\
\hline
\end{tabular}

$\mathrm{T}_{4}=$ Single row cotton+1-row mungbean, $\mathrm{T}_{5}=$ Single row cotton+2-row mungbean, $\mathrm{T}_{6}=$ Single row cotton +3 -row mungbean, $\mathrm{T}_{7}=$ Single row cotton+4-row mungbean, $\mathrm{T}_{8}=$ Paired row cotton+4-row mungbean, $\mathrm{T}_{9}=$ Paired row cotton +5 -row mungbean, $\mathrm{T}_{10}=$ Paired row cotton+6-row mungbean, $\mathrm{T}_{11}=$ Paired row cotton+7-row mungbean.

Market price $\left(\mathrm{Tk} \mathrm{kg}^{-1}\right)$ : Seed cotton-40/-, Mungbean-35/-

\section{Economic evaluation}

Monetary advantages obtained from different spatial arrangements of cotton and mungbean in intercropping systems varied significantly (Table 5). Higher values of gross return (Tk.118039 ha ${ }^{-1}$ ), gross margin (Tk.60220 ha-1) and BCR (2.04) obtained from paired row cotton +4 -row mungbean $\left(\mathrm{T}_{8}\right)$ than the sole cropping. Under intercropping systems, single row cotton +4 -row mungbean $\left(\mathrm{T}_{7}\right)$ showed lower values of gross return (Tk. $88270 \mathrm{ha}^{-1}$ ), gross margin (Tk. $26930 \mathrm{ha}^{-1}$ ) and BCR (1.44). The result of the present study was supported by the findings of Sankaranarayanan et al. (2010) in cotton with vegetables and legumes and Bhatt et al. (2010) in cotton + sesame intercropping system. Higher economic returns from intercropping compared to monocropping was also reported by Macuacua and Santos (2007).

Table 5. Total cost, gross return, gross margin and benefit cost ratio (BCR) as influenced by different spatial arrangements of cotton and mungbean in intercropping systems

\begin{tabular}{c|c|c|c|c}
\hline Treatments & $\begin{array}{c}\text { Total cost } \\
\left(\text { Tk. ha }{ }^{-1}\right)\end{array}$ & $\begin{array}{c}\text { Gross return } \\
\left(\text { Tk. ha }^{-1}\right)\end{array}$ & $\begin{array}{c}\text { Gross margin } \\
\left(\text { Tk. ha }^{-1}\right)\end{array}$ & Benefit cost ratio \\
\hline $\mathrm{T}_{1}$ & 59830 & 115407 & 55570 & 1.93 \\
$\mathrm{~T}_{2}$ & 57380 & 105576 & 48190 & 1.84 \\
$\mathrm{~T}_{3}$ & 26100 & 46258 & 20150 & 1.77 \\
$\mathrm{~T}_{4}$ & 59840 & 112277 & 52440 & 1.87 \\
$\mathrm{~T}_{5}$ & 60370 & 116655 & 56290 & 1.93 \\
$\mathrm{~T}_{6}$ & 60840 & 111022 & 50180 & 1.82 \\
$\mathrm{~T}_{7}$ & 61340 & 88270 & 26930 & 1.44 \\
$\mathrm{~T}_{8}$ & 57810 & 118039 & 60220 & 2.04 \\
$\mathrm{~T}_{9}$ & 58390 & 114269 & 55880 & 1.96 \\
$\mathrm{~T}_{10}$ & 58560 & 111889 & 53330 & 1.90 \\
$\mathrm{~T}_{11}$ & 58750 & 111652 & 52900 & 1.90 \\
\hline LSD $_{(0.05)}$ & 502.2 & 11010 & 10930 & 0.1942 \\
\hline
\end{tabular}

$\mathrm{T}_{1}=$ Sole single row cotton, $\mathrm{T}_{2}=$ Sole paired row cotton, $\mathrm{T}_{3}=$ Sole mungbean, $\mathrm{T}_{4}=$ Single row cotton +1 -row mungbean, $\mathrm{T}_{5}=$ Single row cotton+2-row mungbean, $\mathrm{T}_{6}=$ Single row cotton+3-row mungbean, $\mathrm{T}_{7}=$ Single row cotton+4-row mungbean, $\mathrm{T}_{8}=$ Paired row cotton+4-row mungbean, $\mathrm{T}_{9}=$ Paired row cotton+5-row mungbean, $\mathrm{T}_{10}=$ Paired row cotton+6-row mungbean, $\mathrm{T}_{11}=$ Paired row cotton+7-row mungbean.

Market price $\left(\mathrm{Tk} \mathrm{kg}^{-1}\right)$ : Seed cotton- 40/-, Mungbean- 35/-

\section{Conclusion}


Productivity of Cotton+Mungbean Intercropping Systems

Based on the results of the present experiment it was concluded that paired row cotton +4 -row mungbean was the best combination in relation to LER, equivalent yield, monetary advantage index, economic returns and benefit cost ratio.

\section{References}

Adams, G., S. Boyd and M. Huffman. 2011. Economic outlook for US cotton 2011. National Cotton Council of America. p.70.

Aasim, M., M. U. Ejaz and A. Karim. 2008. Yield and competition indices of intercropping cotton (Gossypium hirsutum L.) using different planting patterns. Tarim Bilimleri Dergisi, 14: 326-333.

Ali, M. O., M. J. Alam, M. S. Alam, M. A. Islam and M. Shahin-Uz-Zaman. 2007. Study on mixed cropping mungbean with sesame at different seeding rates. Int. J. Sustain. Crop Prod. 2: 74-77.

Anonymous. 2011. Directors Report, Bangladesh Textile Mills Association (BTMA), URL: http://www.btmadhaka.com

Anonymous. 2009. Tula Utpadon Kormosuchi. Cotton Development Board. Khamarbari, Farmgate, Dhaka. pp.45-50.

Anonymous.1988. Land Resources Appraisal for Agril. Dev. Rep. 2. Agroecological Regions of Bangladesh, FAO, Rome.

Basavarajappa, R, A. S. Prabhakar and S. I. Halikatti. 2003. Foxtail millet (Setaria italica L.) based intercropping systems under shallow alfisols. Karnataka J. Agril Sci. 16: 514-518.

Bhatt, B. K., S. K. Dixit and V. B. Darji. 2010. Monetary evaluation of sesame based intercropping systems. Indian J. Agril. Res. 44: 146-149.

Bhatti, I. H., R. Ahmad, A. Jabbar, Z. A. Virk and M. Aslam. 2008. Agro-economic performance of mungbean intercropped in sesame under different planting patterns. Pak. J. Agri. Sci. 45: 25-28.

Brammer, H. 1996. The Geography of Soils of Bangladesh, University Pub. Ltd., Dhaka

Das, A. K., Q. A. Khaliq and M. L. Haider. 2012. Efficiency of wheat-lentil and wheat-chickpea intercropping systems at different planting configurations. Int. J. Sustain. Crop Prod. 7: 25-33.

Eskandari, H. 2012. Yield and quality of forage produced in intercropping of maize (Zea mays) with cowpea (Vigna sinensis) and mungbean (Vigna radiata) as double cropped. J. Basic. Appl. Sci. Res. 2: 93-97.

Gomez , K. A. and A. A. Gomez. 1984. Statistical Procedure for Agricultural Research. 2nd edn. John Willey and Sons. Inc. New York. pp.304-307.

Harper, J. L. 1977. Population biology of plants. Academic Press. New York.

Islam, M. N., M. M. Haque and A. Hamid. 2004. Spatial arrangement and population density effects on productivity of maize-bushbean intercropping systems. Bangladesh J. Agril. Res. 29: 467-474.

Junior, E. F., N. M. D. Silva, L. H. Carvalho, N. Bortoletto, J. C. Sabino and D. Bolonhezi. 2003. Types of growth regulator application, planting densities and nitrogen levels for the cotton cultivar IAC 22. Bragantia. 62: 227-233.

Khan, M. A., K. Naveed, K. Ali, B. Ahmad and S. Jan. 2012. Impact of mungbean-maize intercropping on growth and yield of mungbean. Pak. J. Weed Sci. Res.18: 191-200.

Khan, M. B, M. Akhtar and A. Khaliq. 2001. Effect of planting patterns and different intercropping systems on the productivity of cotton (Gossypium hirsutum L.) under irrigated conditions of Faisalabad. Intl. J. Agric. Biol. 3: 432-435. 
Tabib et al.

Mahatale, P. V., U. V. Mahadkar and Y. V. Manatale. 2008. Studies on planting pattern, intercropping and fertilizer levels on growth and yield attributes of irrigated cotton (Cv.Phule-492). Ann. Plant Physiol. 22: 192-195.

Macuacua, R. C. F. and L. Santos. 2007. Evaluation of a cotton-pigeon pea strip-intercropping system in Morrumbala District (Mozambique). 8th African Crop Science Society Conference, El-Minia, Egypt. 27-31-October-2007. pp.231-232.

Maitra, S., D. C. Ghosh, G. Sounda, P. K. Jana and D. K. Roy. 2000. Productivity, competition and economics of intercropping legumes in finger millet (Eleusine coracana) at different fertility levels. Indian J. Agric. Sci. 70: 824-828.

Nataranjan, M. 1990. Statistical analysis of intercropping experiments designed to address basic research issue. In: S. R. Waddington, A. F. E. Palmer, and O. T. Edje (eds), Proceedings of a Workshop on Research Methods for Cereal/Legume Intercropping in Eastern and Southern Africa, 23-27 Jan 1989, at Lilongwe, Malawi, pp.68-73.

Oad, F. C., M. H. Siddiqui and U. A. Buriro. 2007. Agronomic and economic interference between cotton (Gossypium hirsutum L.) and pigeon pea (Cajanus cajan L.) J. Agron. 6: 199-203.

Onuh, M. O., N. C. Ohazurike and A. Ijezie. 2011. Effects of mungbean/melon/maize intercrop on the growth and yield of mungbean (Vigna radiata (L.) Wilczek) cultivated in Owerri Rainforest Area. World J. Agril Sci. 7: 161-165.

Patel, J. G., M. H. Patel, V. Kumar and V. M. Patel. 2010. Possibilities of intercropping in G. Cot. Hy. 10 under irrigated condition. J. Cotton Res. Dev. 24: 160-163.

Rao, V. P. 1991. A study on intercropping of cotton with grain legumes under rainfed conditions. J. Res. , Andra Pradesh Agric.Univ. 19: 73-74.

Sankaranarayanan, K., C. S. Praharaj, P. Nalayini, K. K. Bandyopadhyay and N. Gopalakrishnan. 2010. Legume as companion crop for cotton . J. Cotton Res. Dev. 24: 115-126.

Sanjay, M. T., V. B. Nadagouda, B. T. Pujari, A. Naranagouda and Somshekar. 2003. Intercropping in short duration compact cotton Anjali. Crop Res. Hisar. 26: 224-230.

Sayampol, N. and S. Changsalak. 1997. Add peanut to corn-cotton relay cropping system. Kasetsart J. Nat. Sci. 31: 23-29.

Singh, R. P. and N. S. Jodha. 1990. Determinants of intercropping in the Semi-Arid Tropics (Progress Report). Economics Group Resource Management Program, ICRISAT, Patancheru, Andhra Pradesh, India. Report no. 95. p.14. 
Productivity of Cotton+Mungbean Intercropping Systems 